\title{
Black oats (Avena strigosa Schreb) solubilize rock phosphate and provide phosphorus to the successive crop, grapevine (Vitis labrusca L. 'Red Niagara')
}

\author{
G.W. Melo',a, J.A. Morais Neto², D.R. Borba², H. Iwamoto², K.P.C. Ozelame², J.L. Vieira², \\ J. Zalamena ${ }^{3}$ and A. Nascimento Junior ${ }^{4}$ \\ ${ }^{1}$ Embrapa Grape \& Wine, Bento Gonçalves, Brazil; ${ }^{2}$ State University of Rio Grande do Sul, Bento Gonçalves, Brazil; \\ ${ }^{3}$ Federal University of Santa Maria, Santa Maria, Brazil; ${ }^{4}$ Embrapa Wheat, Bento Gonçalves, Brazil.
}

\begin{abstract}
In grape production, cover crops play a key role in soil protection and nutrient cycling. Thus, since grapevine requirements for $P$ are low, adequate management of cover crops may provide sufficient $P$ for growth. This paper evaluates the effect of black oats, as a cover plant, on the $P$ solubilization in rock phosphate and its availability to the vine cultivated in succession. To test this hypothesis, we evaluated the plants growth parameters and $P$ uptake in grapevines grown in succession to black oats in pots in a greenhouse experiment. The results showed that the soil sterilization decreased $P$ availability to black oats, but not to grapevine. The soil fertilization with rock phosphate increased the $P$ accumulation in oat and grapevine plants, although no further effect was observed from the use the cover crop. The plant height and dry mass contents were higher for grapevine in soils fertilized with rock phosphate and covered with black oats.
\end{abstract}

Keywords: cover crop, rock phosphate, Vitis labrusca, Avena strigose, successive cropping

\section{INTRODUCTION}

Phosphorus (P) is an essential plant nutrient, acting in many metabolic pathways, including respiration, photosynthesis, energy transfer, nucleic acids and protein synthesis (Grant et al., 2001; Jobi, 2013; Lim et al., 2014). Phosphorus fertilization is performed to provide an adequate supply of the nutrient to meet the crop demands, generally using soluble phosphates obtained from the hydrolysis of rock. However, large portions of the applied fertilizer can become unavailable to the plants after soil incorporation (Alves et al., 2002), thus making it necessary to provide a constant or superior than the required supply, as observed for grapevines, whose $P$ requirements are low (Porro et al., 2009). One of the consequences of the frequent application of high dosages of $\mathrm{P}$, known as excessive soil fertilization, is the increased potential of $\mathrm{P}$ transfer by run-off, leading to eutrophication of water springs (Chien et al., 2009; Melo et al., 2012; Yuan et al., 2013). Moreover, there are many reports demonstrating that excessive $P$ usage, coupled with the low efficiency of plants to use different forms of $\mathrm{P}$ in the soil, leads to an increased concentration of $\mathrm{P}$ in crop lands, which is far higher than the optima for crops, at the same time promoting a strong depletion in the world's phosphate resources (Melo and Zalamena, 2016; Messiga et al., 2010; Schröder et al., 2011). Besides environmental pollution, excessive soil fertilization with $\mathrm{P}$ increases the production costs and negatively affects the uptake of micronutrients such as Zn (Singh et al., 1988), because increasing $\mathrm{P}$ doses lead to a reduction in Zn availability. This scenario may induce Zn deficiency symptoms and/or a reduction in the nutrient concentration in the plant.

Therefore, it is necessary to increase the efficiency of phosphate fertilization (Suh and Yee, 2011), and the industry is particularly focused on developing fertilizers that allow the nutrient to remain available to the plants for long periods (Karamanos and Puurveen, 2011;

${ }^{\mathrm{a} E}$-mail: wellington.melo@embrapa.br 
Sakurada et al., 2016), by incorporating new technologies of higher aggregate value. Research to increase the efficiency of P fertilization employing inexpensive sources, such as rock phosphate, is still scarce, and there are also reports of increased efficiency of $P$ fertilization due to the use of cover crops, mainly annual ones (Esteves and Rosolem, 2011; Janegitz et al., 2016; Rodrigues et al., 2009; Rosolem et al., 2014).

Rock phosphates used as $\mathrm{P}$ sources to plants present as a main advantage lower costs in comparison to soluble phosphates, whereas having a better residual effect. In contrast, certain disadvantages are also known, such as the contamination by heavy metals, and to have their low solubility in the soil and its dependency of soil $\mathrm{pH}, \mathrm{Ca}$ and moisture (Chien et al., 2009; de Oliveira et al., 2014). Several recent publications have demonstrated that the inoculation of P-rock with solubilizing microorganisms (MOs) may bypass some these drawbacks (Alves et al., 2002; Barroti and Nahas, 2000; de Carvalho Mendes and dos Reis Júnior, 2003; Sharma et al., 2013). However, it has been reported that the results field trials after MOs inoculation were not satisfactory in comparison to those from the greenhouse, likely due to the large diversity of soil microorganisms, and consequently the occurrence of highly competitive environments (de Carvalho Mendes and dos Reis Júnior, 2003).

The use of cover crops is a viable alternative to increase the efficiency of P-rock fertilization, considering their conditioning action on the soil physical, chemical and biological properties (Barros et al., 2013; Janegitz et al., 2016). Moreover, they are also beneficial to other soil aspects, such as maintenance of edaphic fauna, structural preservation and increases in porosity, nutrient cycling and organic matter. This is generally reflected on the improved performance of the successive crop, which benefits from the increased solubilized P-rock by root exudates, along with retention and cycling of inorganic phosphate $(\mathrm{Pi})$ that incorporates to the organic fractions of the plant tissue.

Therefore, this work was aimed to evaluate the effect of black oats as a cover crop, to solubilize rock phosphate and to provide available $\mathrm{P}$ to grapevines cultivated successively in the same pots.

\section{MATERIAL AND METHODS}

The experiment was carried out in a greenhouse at Embrapa Uva e Vinho, Bento Gonçalves, located at $29^{\circ} 09^{\prime} 44^{\prime \prime}$ south latitude, $51^{\circ} 31^{\prime} 50^{\prime \prime}$ west longitude and at an altitude of approximately $640 \mathrm{~m}$. The soil used is classified as Sandy Typic Hapludalf (Embrapa, 2013), collected from the top layer (0 to $20 \mathrm{~cm}$ ) in the municipality of Bom Princípio (RS). The soil was air dried and passed through a $8 \mathrm{~mm}$ sieve. Soil composition (June 2014) was $\mathrm{pH}$ 4.7, $140 \mathrm{~g} \mathrm{dm}^{-3}$ clay, $6 \mathrm{~g} \mathrm{~kg}^{-1}$ organic matter, $0,03 \mathrm{cmol}_{\mathrm{c}} \mathrm{dm}^{-3}$ available $\mathrm{P}$ and $0,05 \mathrm{cmol}_{\mathrm{c}}$ $\mathrm{dm}^{-3} \mathrm{~K}$ (extracted by Mehlich-1); exchangeable cations (in $\mathrm{cmol}_{\mathrm{c}} \mathrm{dm}^{-3}$ ) Al 1,1, Ca 0,2 and $\mathrm{Mg}$ 0,9 (extracted by KCl $1 \mathrm{~mol} \mathrm{~L}^{-1}$ ); 0,3 $\mathrm{mg} \mathrm{dm}^{-3} \mathrm{~B} ; 2,5 \mathrm{cmol}_{\mathrm{c}} \mathrm{dm}^{-1}$ cation exchange capacity and $140 \mathrm{~g} \mathrm{~kg}^{-1}$ base saturation. Corrective fertilization consisted of the application of $90 \mathrm{~kg} \mathrm{ha}^{-1}$ $\mathrm{K}_{2} \mathrm{O}$ (K chloride, $60 \% \mathrm{~K}_{2} \mathrm{O}$ ), $45 \mathrm{~kg} \mathrm{ha}^{-1} \mathrm{~N}$ (Urea, $45 \% \mathrm{~N}$ ) and $1 \mathrm{~kg} \mathrm{ha}^{-1}$ chelated micronutrients (2\% B, 0.8\% Cu-EDTA, 5.6\% Fe-EDTA, 0.32\% Mo, 3.2\% Mn-EDTA, and 2.0\% Zn-EDTA). After fertilization, the soil was incubated for 30 days at $80 \%$ field capacity.

The experiment was designed as random blocks with four repetitions, and the treatments distributed as a 3-way factorial $(2 \times 2 \times 2)$ : doses of P-rock (zero and $\left.1000 \mathrm{~kg} \mathrm{ha}^{-1}\right)$, cover crop (with/without) and soil sterilization (with/without). Arad P-rock (32.3\% total $\mathrm{P}_{2} \mathrm{O}_{5}, 11.3 \%$ soluble in citric acid) and black oats (Avena strigosa Schreb) 'Comum' were used. Soil sterilization was performed by autoclaving for $45 \mathrm{~min}$ at $120^{\circ} \mathrm{C}$ and $1 \mathrm{~atm}$. The experiment was divided in two stages. During the first stage, black oats were sown (30 seeds per pot), and thinned to 15 plants pot ${ }^{-1}$ after germination. The remaining pots were kept at $80 \%$ field capacity. The cover crop was cultivated for 45 days, subsequently harvested, and returned to the soil surface of the original pots immediately? after determination of the biomass fresh weight. The second experimental stage consisted in planting the grapevine $\mathrm{cv}$. Red Niagara in each pot, with and without the black oat mulch. Grapevine plants were obtained by in vitro micropropagation and gradually acclimated to horticultural substrate in the greenhouse. Before transplantation (July 14), aerial parts and roots were trimmed, keeping only two buds and $4 \mathrm{~cm}$ of roots. Grapevines were then transplanted, grown and 
harvested after 80 days.

For black oats, fresh biomass production was evaluated by weighing with $0.1 \mathrm{~g}$ precision. For grapevines, from the $40^{\text {th }}$ day onwards, four evaluations were carried out for relative index of total chlorophyll (RITC) and plant height at 13 day intervals. RITC was determined using a chlorophyll meter chlorofiLOG ${ }^{\circledR}$ (Falker ${ }^{\circledR}$, model CFL1030) that reads transmittance at wavelengths close to chlorophyll peaks (635 and $660 \mathrm{~nm}$ ) and at near infrared $(880 \mathrm{~nm})$. The leaf is pressed in a capsule during the measurement of the radiation transmitted through the leaf structure. The result is a chlorophyll index, a non-dimensional unit, obtained from the average of three readings of the adaxial surface of the third basal leaf. Plant height was measured with regular measuring tape.

At the end of the experiment, grapevine aerial parts were harvested, dried under forced air circulation at $65^{\circ} \mathrm{C}$ for $72 \mathrm{~h}$, weighed and finely ground to a powder. Phosphorus contents were determined in the soil and for the plant aerial parts, as described by Tedesco et al. (1995).

The resulting data were submitted to analysis of variance to test double and triple interactions. When interactions were significant, factor comparisons were carried out within each factor level. For non-significant interactions, the variables were compared using an Ftest and the factors average.

\section{RESULTS AND DISCUSSION}

According to the results of the analysis of variance (Table 1), there was a significant effect of soil sterilization on black oat fresh biomass weight $(\mathrm{p}<0.01)$, soil $\mathrm{pH}(\mathrm{p}<0.01)$, and RITC $(\mathrm{p}<0.05)$. The addition of P-rock was highly significant $(\mathrm{p}<0.01)$ for all investigated variables except soil $\mathrm{pH}$, and the effect of soil cover was significant for all parameters (at $\mathrm{p}<0.05$ ) except for RITC. Moreover, the interaction between soil sterilization and P-rock addition was also significant $(\mathrm{p}<0.05)$ for black oat fresh biomass, and the interaction between P-rock fertilization and soil cover was significant for P contents in grapevine aerial parts and in the soil.

Table 1. Analysis of variance for $\mathrm{P}$ contents in the soil and accumulated in grapevine aerial part, grapevine plant height (GPH), relative index total chlorophyll (RITC), black oat roots fresh weight (SFW) and grapevine dry matter (GDM).

\begin{tabular}{|c|c|c|c|c|c|c|}
\hline \multirow[b]{2}{*}{ Variable } & \multicolumn{6}{|c|}{ Factors } \\
\hline & $\begin{array}{l}\text { Sterilization } \\
\text { (S) }\end{array}$ & $\begin{array}{l}\text { P-Rock } \\
\text { (P) }\end{array}$ & $\begin{array}{l}\text { Black oats } \\
\text { (C) }\end{array}$ & SXP & $S \times C$ & $P \times C$ \\
\hline Black oats fresh biomass weight & $* *$ & $* *$ & - & * & - & - \\
\hline$P$ content in grapevine aerial parts & ns & ** & * & ns & ns & * \\
\hline$P$ contents in the soil & ns & ** & * & ns & ns & * \\
\hline Grapevine plant height & ns & ** & * & ns & ns & ns \\
\hline Total chlorophyll relative index & * & ** & ns & ns & ns & ns \\
\hline Soil pH & ** & ns & * & ns & ns & ns \\
\hline Grapevine dry matter & ns & ** & * & ns & ns & ns \\
\hline
\end{tabular}

ns non-significant, - not determined, * and ** Significant according to $F$ test at 5 and $1 \%$ probability, respectively.

At the first stage of the experiment, the addition of P-rock increased significantly the black oat fresh biomass yield (Table 2), leading to yields 21 and 13.5 times higher in comparison to the treatments with and without soil sterilization, respectively (Table 2). The differences in black oat biomass yield are likely due to delayed cell growth under severe $\mathrm{P}$ deficiency (Grant et al., 2001).

Microorganism population influenced the availability of $\mathrm{P}$ to black oats, as shown in Table 2, since sterilization improved significantly fresh biomass yield for treatments with Prock, whereas in the absence of P-rock fertilization yields were not significantly different 
with and without sterilization. The results support that, under conditions of low availability of $\mathrm{P}$, the microorganisms did not have the capacity to increase the availability of P. However, several authors report that microorganisms may increase the $\mathrm{P}$ availability from rock phosphate to plants, due to the large diversity of organisms such as fungi, bacteria and some algae with the aforementioned ability (de Carvalho Mendes and dos Reis Júnior, 2003; Sharma et al., 2013). In particular, this applies to fungi, which are known to possess the most prominent activity in solubilizing P-rock, since these organisms in general produce higher levels of organic acids than bacteria (Venkateswarlu et al., 1984).

Table 2. Black oats fresh biomass production (g pot $\left.{ }^{-1}\right)$ with sterilized or non-sterilized soil and in the presence or absence of rock phosphate (P-rock) fertilization.

\begin{tabular}{lccc}
\hline \multirow{2}{*}{ Soil sterilization } & \multicolumn{2}{c}{ P-rock fertilization } & \multirow{2}{*}{ Significance } \\
\cline { 2 - 3 } & Present & Absent & \\
\hline Present & 46.2 & 2.2 & $*$ \\
Absent & 55.6 & 4.1 & $*$ \\
\hline Significance & $* *$ & $n s$ & \\
\hline${ }^{* *}=$ significant and $n s=$ non-significant according to the F-test $(p<0.05)$. &
\end{tabular}

As shown in Table 3, soil pH was significantly affected by sterilization and the presence of the cover crop, with lower $\mathrm{pH}$ in the absence of sterilization and the soil cover presence, whereas fertilization with P-rock has no significant effect. These results support the hypothesis of competitive adsorption between organic acids and $\mathrm{P}$ in soil colloids. Besides solubilizing P-rock by acidification, the hydrolysis of insoluble $\mathrm{P}$ to available forms may occur by the action of phosphatase enzymes, reflecting the action of plants and soil MOs, which secrete these enzymes mainly under low P availability (Kapri and Tewari, 2010; Nahas, 2002).

Table 3. Soil pH after grapevine plant removal.

\begin{tabular}{lcccccc}
\hline \multirow{2}{*}{ Variable } & \multicolumn{2}{c}{ Soil sterilization } & P-rock fertilization & \multicolumn{2}{c}{ Soil cover (black oats) } \\
\cline { 2 - 7 } & Present & Absent & Present & Absent & Present & Absent \\
\hline $\mathrm{pH}$ & 4.85 & 4.41 & 4.68 & 4.59 & 4.56 & 4.76 \\
\hline Significance & \multicolumn{3}{c}{ ns } \\
\hline${ }^{* *}=$ significant and $\mathrm{ns}=$ non-significant according to F-test $(\mathrm{p}<0.05)$. & \multicolumn{3}{c}{${ }^{* *}$}
\end{tabular}

As shown in Figure 1A, grapevine aerial parts accumulate lower levels of $P$ in the treatments without P-rock fertilization, regardless of the presence of the cover crop. In contrast, the presence the cover crop led to a higher P accumulation with P-rock fertilization.

The use of black oats as cover crop did not influence the levels of extractable P from the soils in the absence P-rock fertilization (Figure 1B). However, when P-rock fertilization was used the presence of the cover crop reduced somewhat the contents of extractable P. These observations are likely to be due to the larger accumulation of $\mathrm{P}$ in grapevine and black oats, suggesting that black oats may have contributed to increase P availability in the soil, since the cover crop accumulated a portion of extractable $\mathrm{P}$ and promoted nutrient accumulation in grapevine.

Our results corroborate the study by Pavinato and Rosolem (2008) which showed that an addition of plant residues can increase the phosphorus availability in the soil, due to $\mathrm{P}$ in the plant residue or the competition of residue-derived organic compounds for soil $\mathrm{P}$ adsorption sites. This contributes to an increased $\mathrm{P}$ availability in the soil solution, similar to the action of organic anions present in the rhizosphere, released from cover crops or by grapevines, which can also interfere with P status in the soil (Lopez-Hernandez et al., 1986). 

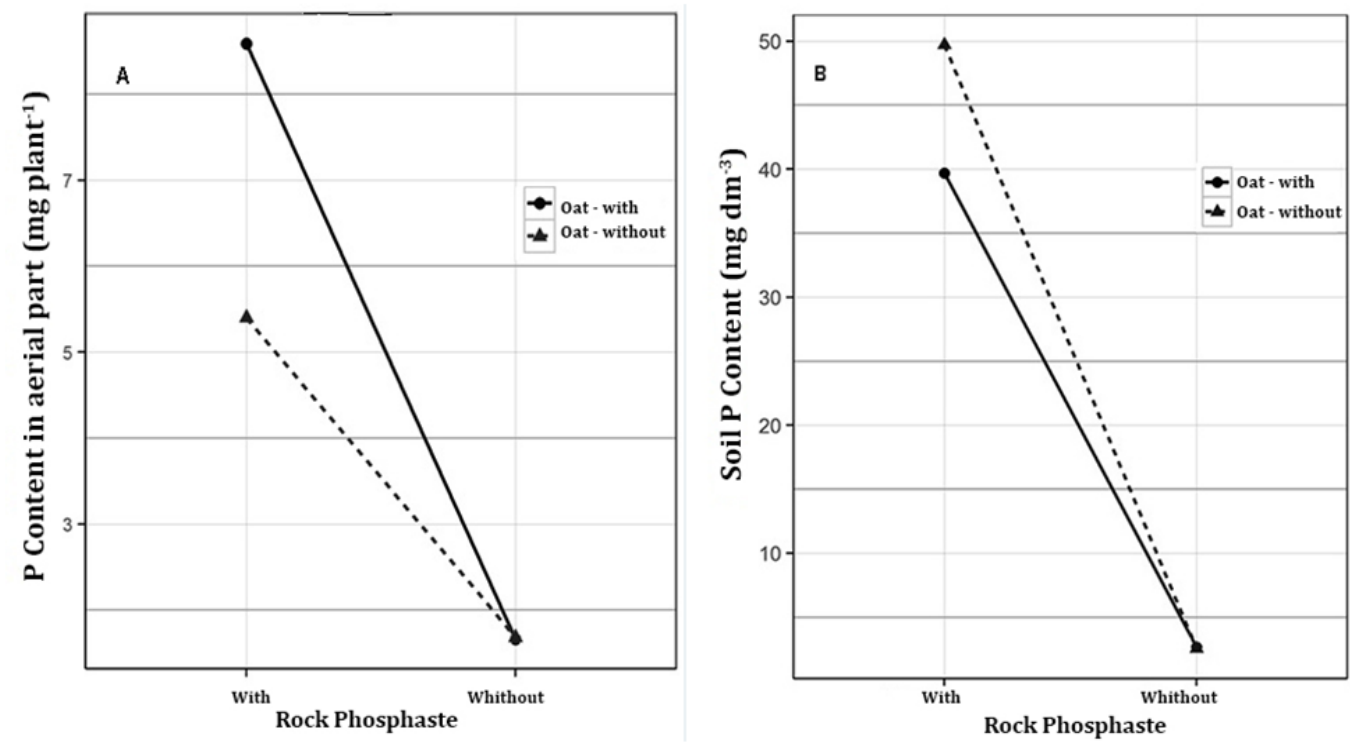

Figure 1. Phosphorus content in grapevine aerial parts (mg plant $\left.{ }^{-1}\right)(A)$ and available soil $P$ content $\left(\mathrm{mg} \mathrm{dm}^{-3}\right)$ after the cultivation of grapevine (B), depending on the presence of P-rock fertilization and black oats soil cover.

The use of black oats as a cover crop and soil sterilization had no influence on grapevine RITC until day 53 (Figure 2); however, at days 66 and 80 soil sterilization and Prock fertilization promoted slight (4.5 and 5.4\%, respectively) increases in RITC (Figure 2). These effects may be due to the death of soil microorganisms, that can promote a decrease of soil $\mathrm{P}$ availability, consequently generating a deficiency of $\mathrm{P}$ in the plants, which is typically characterized by leaf darkening, from dark green to purple depending on symptom severity (Grant et al., 2001). Favela et al. (2006) report similar symptoms, coupled with possible irregular discoloration brown or purple spots, starting from the lower end of older leaves, due to the accumulation of anthocyanins. The changes in leaf color interfere with RITC readings.

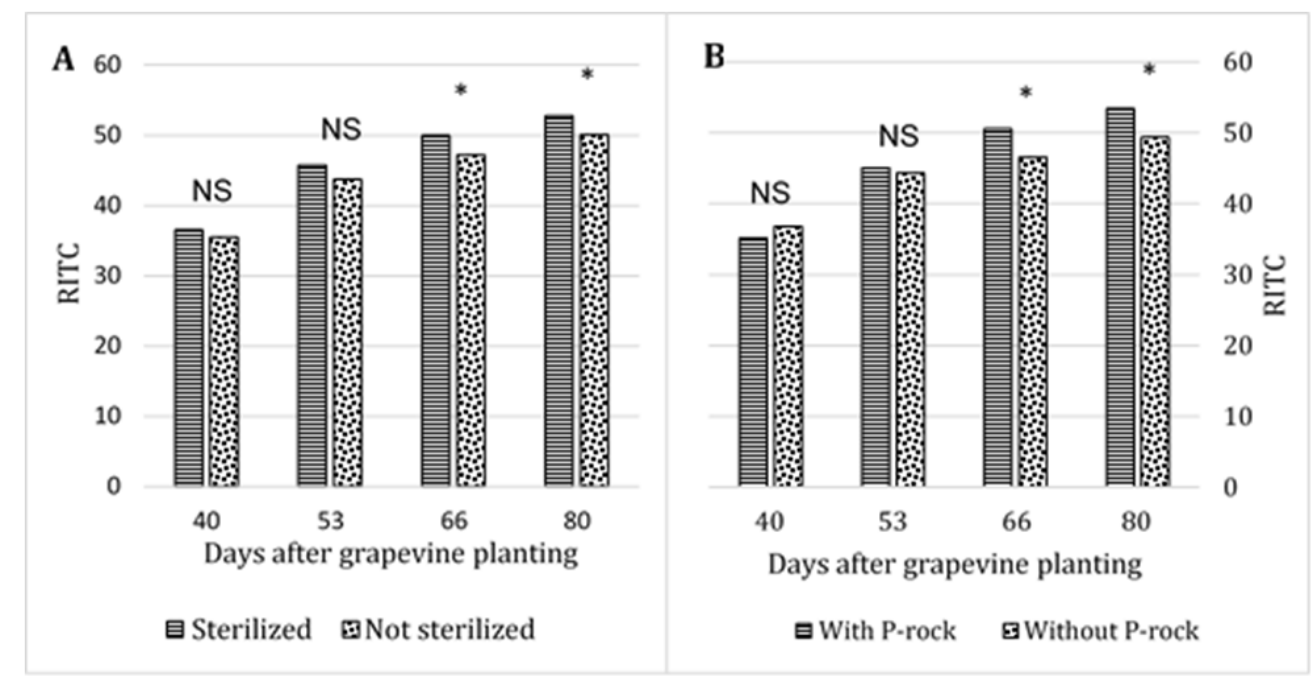

Figure 2. Changes in relative index of total chlorophyll (RITC) throughout grapevine growth depending on the presence of soil sterilization (A) and P-rock fertilization (B). $*$ = significant; NS = non-significant according to F-test $(\mathrm{p}<0.05)$. 
The application of P-rock fertilizer, as expected, contributed to a significant increase in grapevine plant height (Table 4), since $\mathrm{P}$ is a critical element in plant metabolism, acting mainly on photosynthesis, respiration and energy transfer and therefore promoting growth (Gatiboni, 2003; Grant et al., 2001).

Table 4. Grapevine plant height (GPH), in $\mathrm{cm}$, cultivated in soil in the presence and absence of P-rock fertilization.

\begin{tabular}{lcccc}
\hline Days after grapevine & Soil cover & \multicolumn{2}{c}{ P-rock fertilization } & \multirow{2}{*}{ Mean } \\
\cline { 3 - 4 } planting & (black oats) & Present & Absent & \\
\hline 40 & Present & 22.9 & 24.6 & $23.8 \mathrm{~A}$ \\
& Absent & 24.1 & 20.4 & $22.3 \mathrm{~A}$ \\
& Mean & $23.5 \mathrm{a}$ & $22.5 \mathrm{a}$ & \\
\hline 53 & Present & 34.9 & 28.8 & $31.9 \mathrm{~A}$ \\
& Absent & 32.7 & 23.4 & $28.1 \mathrm{~A}$ \\
& Mean & $33.8 \mathrm{a}$ & $26.1 \mathrm{~b}$ & \\
\hline 66 & Present & 50.0 & 29.8 & $39.9 \mathrm{~A}$ \\
& Absent & 39.0 & 24.5 & $31.8 \mathrm{~B}$ \\
& Mean & $44.5 \mathrm{a}$ & $27.2 \mathrm{~b}$ & \\
\hline 80 & Present & 71.0 & 30.3 & $50.7 \mathrm{~A}$ \\
& Absent & 49.8 & 25.0 & $37.4 \mathrm{~B}$ \\
& Mean & $60.4 \mathrm{a}$ & $27.7 \mathrm{~b}$ & \\
\hline
\end{tabular}

Means followed by equal letters, small caps for the line and capitalized for the rows, are not significantly different according to F-test $(p<0.05)$.

The use of black oats as a cover crop had no effect on the grapevines up to the $53^{\text {rd }}$ day after planting, although from the third evaluation on, 13 days later, it did cause a significant increase on grapevine plant height (Table 4). The increased height can be explained by the decomposition and liberation of nutrients from the cover crop mulch, which guaranteed a better nutrient support for grapevine growth in the long term.

The application of P-rock fertilization had no effect on grapevine mean height nor on RITC up to the 40 and 53 days after planting, respectively. However, 66 days after planting a significant increase in both variables was observed (Table 4; Figure 2B). The observations may be due to nutritional reserves in the root system of grapevines, which, although limited by trimming, could still be able to provide $\mathrm{P}$ for a relatively long period of time. Alternatively, the effect may be due to the time required by the grapevines to adapt to a novel concentration of P available in the soil. According to Vasconcelos and Raghothama (2006), the variation in soil nutrient contents may affect uptake by direct modulation of $\mathrm{P}$ transporters activity and gene expression induction.

The supply of P-rock as well as the use of black oats as a cover crop, favored an increase in the aerial part biomass of grapevines (Table 5). The observed response is likely to be associated to the functions performed by $\mathrm{P}$ in plants, since, besides its structural role, it also participates in the composition of organic compounds, such as ATP, amino acids and enzymes (Hendrickson et al., 2004; Nyoki and Ndakidemi, 2014). The increase in plant yield in the presence of the cover crop was possibly due to its effect on the P-rock fertilizer. Several authors have reported the possible mechanisms developed by the soil microorganisms and the plants (Deubel et al., 2000; Hoberg et al., 2005; Hoffland et al., 1989; Illmer and Schinner, 1995; Marschner, 2008; Richardson, 2001), by which the plants release organic acids to the soil via roots. These compounds contact with fertilizer particles, thus contributing to solubilize $\mathrm{P}$, and consequently increasing $\mathrm{P}$ uptake by plants. Moreover, rhizodeposition, liberation of organic compounds, may contribute to raise the population of $\mathrm{P}$ solubilizing microorganisms, which is also responsible for the increase in $\mathrm{P}$ adsorption (Dobbelaere et al., 2003; Hoffland et al., 1989; Janegitz et al., 2016; Khan et al., 2010; Kolawole et al., 2013; Richardson, 2001; Saxena et al., 2015; Walpola and Yoon, 2013). 
Table 5. Dry matter (DM) of the aerial parts of grapevine cultivated in presence or absence of black oats as a cover crop and the presence or absence of P-rock fertilization.

\begin{tabular}{lcccc}
\hline \multirow{2}{*}{ Variable } & Soil cover & \multicolumn{2}{c}{ P-rock fertilization } & \multirow{2}{*}{ Mean } \\
\cline { 3 - 4 } (black oats) & Presence & Absence & \\
\hline DM aerial parts $(\mathrm{g})$ & Presence & 6.55 & 3.08 & $4.82 \mathrm{~A}$ \\
& Absence & 4.93 & 2.78 & $3.86 \mathrm{~B}$ \\
& Mean & $5.74 \mathrm{a}$ & $2.93 \mathrm{~b}$ & \\
\hline
\end{tabular}

Means followed by equal letters, small caps for the line and capitalized for the rows, are not significantly different according to F-test $(p<0.05)$.

Soil sterilization had no effect on mean GPH or GDM (Table 6). Several authors have reported beneficial and deleterious effects on plant development (De Deyn et al., 2004; Farzaneh et al., 2011; Luo et al., 2017; Schradin and Cipollini, 2012). The discrepancies may be associated to local microflora diversity, as plant-microbe relationship is affected by biotic and abiotic factors, such as plant species and soil physicochemical characteristics (Brimecombe et al., 2001). Moreover, the lack of significant differences between treatments in the presence and absence of soil sterilization for plant height and dry biomass may be due to the indirect effect of the sterilization method employed, since some reports by Berns et al. (2008), Katan and DeVay (1991) and Stromme (1962) have demonstrated an effective increase in $\mathrm{N}$ contents in the soil solution after autoclaving, which may have contributed to increase grapevine vigor on sterilized soil, even in the absence of MOs.

Table 6. Grapevine plant height and aerial part dry biomass in plants cultivated in the presence or absence of soil sterilization.

\begin{tabular}{|c|c|c|c|c|c|}
\hline \multirow{2}{*}{ Soil sterilization } & \multicolumn{4}{|c|}{ Plant height $(\mathrm{cm})$} & \multirow{2}{*}{ Aerial parts DW } \\
\hline & 1 & 2 & 3 & 4 & \\
\hline Present & $23.6 a$ & $31.4 a$ & $38.6 a$ & $46.3 a$ & $4.29 a$ \\
\hline Absent & $22.4 a$ & $28.5 a$ & $33.0 \mathrm{a}$ & $41.8 \mathrm{a}$ & $4.37 a$ \\
\hline
\end{tabular}

Means followed by equal letters, small caps for the line and capitalized for the rows, are not significantly different according to F-test $(\mathrm{p}<0.05)$.

\section{FINAL CONSIDERATIONS}

Phosphorus contents in the soil in the absence of P-rock fertilization were below grapevine and black oat physiological requirements, as demonstrated by the increase of $\mathrm{P}$ in plant tissues and enhanced growth.

In the current work, the presence of black oat as a cover crop and soil sterilization acted distinctly on Arad rock phosphate. The presence of soil sterilization had no influence on plant height and dry biomass production. In contrast, the use of black oats as cover crop led to higher $\mathrm{P}$ accumulation in grapevine aerial parts, indicating that black oats have mechanisms contributing to solubilize P-rock and provide available P to the succesion crop grapevine.

\section{ACKNOWLEDGEMENTS}

The authors thank Fundação de Amparo à Pesquisa do Estado do Rio Grande do Sul (FAPERGS), Conselho Nacional de Desenvolvimento Científico e Tecnológico (CNPq), and Financiadora de Estudos e Projetos (FINEP) for financial support. We are also grateful to Embrapa Uva e Vinho staff analist, Volmir Scanagatta for the laboratorial analyses and to researcher Dr. Vera M. Quecini for the revision of the manuscript. 


\section{Literature cited}

Alves, L., Mendoza, E.A., and Silva Filho, G.N. (2002). Microrganismos solubilizadores de fosfatos e o crescimento de pínus e eucalipto. Rev. Bras. Ciênc. Solo 26 (4), 939-947 https://doi.org/10.1590/S010006832002000400011.

Barros, D.L., de Gomide, P.H.O., and Carvalho, G.J. (2013). Plantas de cobertura e seus efeitos na cultura em sucessão. Biosci. J. 29, 308-318.

Barroti, G., and Nahas, E. (2000). População microbiana total e solubilizadora de fosfato em solo submetido a diferentes sistemas de cultivo. Pesqui. Agropecu. Bras. 35 (10), 2043-2050 https://doi.org/10.1590/S0100$204 X 2000001000016$

Berns, A.E., Philipp, H., Narres, H.D., Burauel, P., Vereecken, H., and Tappe, W. (2008). Effect of gamma-sterilization and autoclaving on soil organic matter structure as studied by solid state NMR, UV and fluorescence spectroscopy. Eur. J. Soil Sci. 59 (3), 540-550 https://doi.org/10.1111/j.1365-2389.2008.01016.x.

Brimecombe, M.J., De Leij, F.A., and Lynch, J.M. (2001). The effect of root exudates on rhizosphere microbial populations. In The Rhizosphere - Biochemistry and Organic Substances at the Soil-Plant Interface, R. Pinton, Z. Varanini, and P. Nannipieri, eds. (Marcel Dekker Inc., New York), p.95-140.

Chien, S.H., Prochnow, L.I., and Cantarella, H. (2009). Recent developments of fertilizer production and use to improve nutrient efficiency and minimize environmental impacts. In Advances in Agronomy (Elsevier Inc.), p.267-322.

de Carvalho Mendes, I., and dos Reis Júnior, F.B. (2003). Microrganismos e disponibilidade de fósforo (P) nos solos: uma análise crítica. EMBRAPA Documentos $85,9-25$

De Deyn, G.B., Raaijmakers, C.E., and Van Der Putten, W.H. (2004). Plant community development is affected by nutrients and soil biota. J. Ecol. 92 (5), 824-834 https://doi.org/10.1111/j.0022-0477.2004.00924.x.

de Oliveira, L.B., Tiecher, T., de Quadros, F.L.F., Trindade, J.P.P., Gatiboni, L.C., Brunetto, G., and dos Santos, D.R (2014). Formas de fósforo no solo sob pastagens naturais submetidas à adição de fosfatos. Rev. Bras. Ciênc. Solo 38 (3), 867-878 https://doi.org/10.1590/S0100-06832014000300018.

Deubel, A., Gransee, A., and Merbach, W. (2000). Transformation of organic rhizodepositions by rhizosphere bacteria and its influence on the availability of tertiary calcium phosphate. J. Plant Nutr. Soil Sci. 163 (4), 387-392 https://doi.org/10.1002/1522-2624(200008)163:4<387:AID-JPLN387>3.0.CO;2-K.

Dobbelaere, S., Vanderleyden, J., and Okon, Y. (2003). Plant growth-promoting effects of Diazotrophs in the Rhizosphere. CRC. Crit. Rev. Plant Sci. 22 (2), 107-149 https://doi.org/10.1080/713610853.

Embrapa, E.B.D.P.A. (2013). Sistema Brasileiro de Classificação de Solos (Brasília: Empresa Brasileira de Pesquisa Agropecuária - EMBRAPA).

Esteves, J.A. de F., and Rosolem, C.A. (2011). Triticale, milheto e adubação fosfatada para formação de palhada em semeadura direta. Rev. Bras. Ciênc. Solo 35 (3), 981-990 https://doi.org/10.1590/S0100-06832011000300032.

Farzaneh, M., Vierheilig, H., Lössl, A., and Kaul, H.P. (2011). Arbuscular mycorrhiza enhances nutrient uptake in chickpea. Plant Soil Environ. 57 (10), 465-470 https://doi.org/10.17221/133/2011-PSE.

Favela, E.C., Rangel, P.P., and Benavides, A.M. (2006). Manual para la Preparación de Soluciones Nutritivas (Mexico: UAAAN).

Gatiboni, L.C. (2003). Disponibilidade de Formas de Fósforo do Solo às Plantas (Santa Maria, Brazil: Universidade Federal de Santa Maria).

Grant, C.A., Flaten, D.N., Tomasiewicz, D.J., and Sheppard, S.C. (2001). A importância do fósforo no desenvolvimento inicial da planta. Inf. Agron. 95, 1-16.

Hendrickson, L., Chow, W.S., and Furbank, R.T. (2004). Low temperature effects on grapevine photosynthesis: the role of inorganic phosphate. Funct. Plant Biol. 31 (8), 789-801 https://doi.org/10.1071/FP04037.

Hoberg, E., Marschner, P., and Lieberei, R. (2005). Organic acid exudation and pH changes by Gordonia sp. and Pseudomonas fluorescens grown with $\mathrm{P}$ adsorbed to goethite. Microbiol. Res. 160 (2), 177-187 https://doi.org/10.1016/j.micres.2005.01.003. PubMed

Hoffland, E., Findenegg, G.R., and Nelemans, J.A. (1989). Solubilization of rock phosphate by rape. Plant Soil 113 (2), 161-165 https://doi.org/10.1007/BF02280176.

Illmer, P., and Schinner, F. (1995). Solubilization of inorganic calcium phosphates-Solubilization mechanisms. Soil Biol. Biochem. 27 (3), 257-263 https://doi.org/10.1016/0038-0717(94)00190-C. 
Janegitz, M.C., de Souza, E.A., and Rosolem, C.A. (2016). Brachiaria as a cover crop to improve phosphorus use efficiency in a no-till oxisol. Rev. Bras. Ciênc. Solo 40 (0), e0150128 https://doi.org/10.1590/ 18069657 rbcs20150128.

Jobi, T.O. (2013). Detoxification and accumulation of cadmium and arsenic in plants: implications for phytoremediation and limiting accumulation in foods. Thesis (San Diego: University of California).

Kapri, A., and Tewari, L. (2010). Phosphate solubilization potential and phosphatase activity of rhizospheric trichoderma spp. Braz. J. Microbiol. 41 (3), 787-795 https://doi.org/10.1590/S1517-83822010005000001. PubMed

Karamanos, R.E., and Puurveen, D. (2011). Evaluation of a polymer treatment as enhancer of phosphorus fertilizer efficiency in wheat. Can. J. Soil Sci. 91 (1), 123-125 https://doi.org/10.4141/cjss10071.

Katan, J., and DeVay, J.E. (1991). Soil Solarization (Boca Ratòn, Florida: CRC Press), pp.267.

Khan, M.S., Zaidi, A., Ahemad, M., Oves, M., and Wani, P.A. (2010). Plant growth promotion by phosphate solubilizing fungi - current perspective. Arch. Agron. Soil Sci. 56 (1), 73-98 https://doi.org/10.1080/ 03650340902806469.

Kolawole, G.O., Adigun, C.O., Akintade, B.O., and Lawal, B. (2013). Organic residues affect soil P availability, cowpea yield and nutrient uptake on a near neutral P-deficient alfisol in southwestern Nigeria. Int. J. Appl. Agric. Apic. Res. 9, 81-90.

Lim, H., Cho, M.H., Bhoo, S.H., and Hahn, T.R. (2014). Pyrophosphate: fructose-6-phosphate 1-phosphotransferase is involved in the tolerance of Arabidopsis seedlings to salt and osmotic stresses. Vitr. Cell. Dev. Biol. Plant 50 (1), 84-91 https://doi.org/10.1007/s11627-013-9578-9.

Lopez-Hernandez, D., Siegert, G., and Rodriguez, J.V. (1986). Competitive adsorption of phosphate with malate and oxalate by tropical soils. Soil Sci. Soc. Am. J. 50 (6), 1460-1462 https://doi.org/10.2136/ sssaj1986.03615995005000060016x.

Luo, S., De Deyn, G.B., Jiang, B., and Yu, S. (2017). Soil biota suppress positive plant diversity effects on productivity at high but not low soil fertility. J. Ecol. 105 (6), 1766-1774 https://doi.org/10.1111/13652745.12773.

Marschner, P. (2008). The Role of Rhizosphere Microorganisms in Relation to P Uptake by Plants (The Netherlands: Springer), p.165-176.

Melo, G.W., and Zalamena, J. (2016). Retrato da fertilidade de solos cultivados com videira nas regiões da Serra e Campanha Gaúcha. Comun. Técnico 181, 1-9.

Melo, G.W.B. de, Brunetto, G., Schmitt, D.E., Gatiboni, L.C., Heinzen, J., Oliveira, B.S., Ambrosini, V.G., Moraes, M.P., and Miotto, A. (2012). Acúmulo de fósforo em solos cultivados com videiras na região da Campanha Gaúcha. Comun. Técnico Embrapa Uva E Vinho 131, 1-7.

Messiga, A.J., Ziadi, N., Plénet, D., Parent, L.E., and Morel, C. (2010). Long-term changes in soil phosphorus status related to $\mathrm{P}$ budgets under maize monoculture and mineral P fertilization. Soil Use Manage. 26 (3), 354-364 https://doi.org/10.1111/j.1475-2743.2010.00287.x.

Nahas, E. (2002). Microrganismos do solo produtores de fosfatases em diferentes sistemas agrícolas. Bragantia 61 (3), 267-275 https://doi.org/10.1590/S0006-87052002000300008.

Nyoki, D., and Ndakidemi, P.A. (2014). Effects of phosphorus and Bradyrhizobium japonicum on growth and chlorophyll content of cowpea (Vigna unguiculata (L.) Walp). Am. J. Exp. Agric. 4 (10), 1120-1136 https://doi.org/10.9734/AJEA/2014/6736.

Pavinato, P.S., and Rosolem, C.A. (2008). Disponibilidade de nutrientes no solo: decomposição e liberação de compostos orgânicos de resíduos vegetais. Rev. Bras. Ciênc. Solo 32 (3), 911-920 https://doi.org/10.1590/ S0100-06832008000300001.

Porro, D., Dorigatti, C., Zatelli, A., Ramponi, M., Stefanini, M., and Policarpo, M. (2009). Partitioning of dry matter in grapevines during a season: estimation of nutrient requirements. Progrès Agric. Vitic. 126, 184-188.

Richardson, A.E. (2001). Prospects for using soil microorganisms to improve the acquisition of phosphorus by plants. Funct. Plant Biol. 28 (9), 897-906 https://doi.org/10.1071/PP01093.

Rodrigues, C.R., Faquin, V., de Ávila, F.W., Rodrigues, T.M., Baliza, D.P., and de Oliveira, E.A.B. (2009). Crescimento e acúmulo de fósforo pela soja cultivada em sucessão a diferentes gramíneas forrageiras adubadas com super fosfato triplo e fosfato reativo de arad. Cienc. Agrotec. 33 (6), 1486-1494 https://doi.org/10.1590/S141370542009000600005 .

Rosolem, C.A., Merlin, A., and Bull, J.C.L. (2014). Soil phosphorus dynamics as affected by Congo grass and P fertilizer. Sci. Agric. 71 (4), 309-315 https://doi.org/10.1590/0103-9016-2013-0345. 
Sakurada, L.R., Batista, M.A., Inoue, T.T., Muniz, A.S., and Pagliari, P.H. (2016). Organomineral phosphate fertilizers: agronomic efficiency and residual effect on initial corn development. Agron. J. 108 (5), 2050-2059 https://doi.org/10.2134/agronj2015.0543.

Saxena, J., Saini, A., Ravi, I., Chandra, S., and Garg, V. (2015). Consortium of phosphate-solubilizing bacteria and fungi for promotion of growth and yield of chickpea (Cicer arietinum). J. Crop Improv. 29 (3), 353-369 https://doi.org/10.1080/15427528.2015.1027979.

Schradin, K., and Cipollini, D. (2012). The sign and strength of plant-soil feedback for the invasive shrub, Lonicera maackii, varies in different soils. Forests 3 (4), 903-922 https://doi.org/10.3390/f3040903.

Schröder, J.J., Smit, A.L., Cordell, D., and Rosemarin, A. (2011). Improved phosphorus use efficiency in agriculture: a key requirement for its sustainable use. Chemosphere 84 (6), 822-831 https://doi.org/10.1016/ j.chemosphere.2011.01.065. PubMed

Sharma, S.B., Sayyed, R.Z., Trivedi, M.H., and Gobi, T.A. (2013). Phosphate solubilizing microbes: sustainable approach for managing phosphorus deficiency in agricultural soils. Springerplus 2 (1), 587 https://doi.org/ 10.1186/2193-1801-2-587. PubMed

Singh, J.P., Karamanos, R.E., and Stewart, J.W.B. (1988). The mechanism of phosphorus-induced zinc deficiency in bean (Phaseolus vulgaris L.). Can. J. Soil Sci. 68 (2), 345-358 https://doi.org/10.4141/cjss88-032.

Stromme, E. (1962). The effect of soil steaming on the ammonia and nitrate content of the soil and on the growth of tomato plants. Acta Agric. Scand. 12 (1-2), 16-48 https://doi.org/10.1080/00015126209433058.

Suh, S., and Yee, S. (2011). Phosphorus use-efficiency of agriculture and food system in the US. Chemosphere 84 (6), 806-813 https://doi.org/10.1016/j.chemosphere.2011.01.051. PubMed

Tedesco, M.J., Gianello, C., Bissani, C.A., Bohnen, H., and Volkweiss, S.J. (1995). Análise de Solo, Plantas e Outros Materiais (Porto Alegre, Brazil: Universidade Federal do Rio Grande do Sul).

Vasconcelos, M.J.V., and Raghothama, K.G. (2006). Análise da expressão de genes induzidos por fósforo em genótipos contrastantes de milho selecionados para eficiência do uso de fósforo. In Congresso Nacional de Milho e Sorgo 26. Simpósio Brasileiro Sobre a Lagarta-do-Cartucho (Spodoptera frugiperda) 2; Simpósio Sobre Colletotrichum graminicola 1 (Belo Horizonte, Brazil: ABMS).

Venkateswarlu, B., Rao, A.V., and Raina, P. (1984). Evaluation of phosphorus solubilisation by microorganisms isolated from aridisols. J. Indian Soc. Soil Sci. 32, 273-277.

Walpola, B.C., and Yoon, M.H. (2013). Phosphate solubilizing bacteria: assessment of their effect on growth promotion and phosphorous uptake of mung bean (Vigna radiata (L.) R. Wilczek). Chil. J. Agric. Res. 73 (3), 275281 https://doi.org/10.4067/S0718-58392013000300010.

Yuan, Y., Locke, M.A., Bingner, R.L., and Rebich, R.A. (2013). Phosphorus losses from agricultural watersheds in the Mississippi Delta. J. Environ. Manage. 115, 14-20 https://doi.org/10.1016/j.jenvman.2012.10.028. PubMed 